\title{
How To Help Restaurants Survive during COVID-19?
}

\author{
BAYU ILHAM PRADANA ${ }^{1}$, PUSVITA YUANA ${ }^{2}$, RISCA FITRI AYUNI ${ }^{3}$, ANNISA MAHARANI AMIR ${ }^{4}$, \\ AISHA KARUNIA KARTIKA ${ }^{5}$ \\ ${ }^{1}$ Department of Management, UNIVERSITAS BRAWIJAYA, INDONESIA, E-mail: bayuilham@ub.ac.id \\ 2Department of Management, UNIVERSITAS BRAWIJAYA, INDONESIA, E-mail: pusvita.yuana@ub.ac.id \\ ${ }^{3}$ Department of Management, UNIVERSITAS BRAWIJAYA, INDONESIA, E-mail: risca.fa@ub.ac.id \\ ${ }^{4}$ Department of Management, UNIVERSITAS BRAWIJAYA, INDONESIA, E-mail: annisaamirr@gmail.com \\ ${ }^{5}$ Department of Management, UNIVERSITAS BRAWIJAYA, INDONESIA, E-mail: aishakarunia@student.ub.ac.id
}

\begin{abstract}
COVID-19 occurred in early 2020 which led to social restrictions, physical distancing, and even large-scale social restrictions (PSBB) in Malang City. This impact has massively shattered the social and economic foundations of Indonesia. This research is aimed to investigate the impact of health surveillance trust, perceived safety and restaurant brand, solidarity with the food services towards revisiting intention, intention to visit other restaurants, and word of mouth through satisfaction in Malang restaurants. Two hundred and fifty respondents participated in this study. To achieve the aim of this study, SmartPLS3 software was used. The research method used is a survey through the distribution of questionnaires. Survey results through questionnaires were inputted, tabulated, and processed for later analysis using SmartPLS3 software. As predicted, health surveillance trust, perceived safety and restaurant brand, solidarity with the food services had a significant effect on satisfaction. In addition, the effect of satisfaction on revisit intention, intention to visit other restaurants, and word of mouth has been proven in this study. From a practical standpoint, it is obvious that to help restaurants survive, the government and the community can work together to build empathy and solidarity with the restaurants as well as comply with health and safety protocols.
\end{abstract}

Keywords: Health Surveillance Trust; Perceived Safety and Restaurant Brand; Solidarity with The Food Services; Intention to Visit; Word of Mouth.

JEL Classification: M21, M31, M30

Received: June 05, 2021

Accepted: September 27, 2021 


\title{
¿Cómo Ayudar a los Restaurantes a Sobrevivir durante COVID-19?
}

\author{
BAYU ILHAM PRADANA ${ }^{1}$, PUSVITA YUANA ${ }^{2}$, RISCA FITRI AYUNI ${ }^{3}$, ANNISA MAHARANI AMIR ${ }^{4}$ \\ AISHA KARUNIA KARTIKA ${ }^{5}$ \\ ${ }^{1}$ Department of Management, UNIVERSITAS BRAWIJAYA, INDONESIA, E-mail: bayuilham@ub.ac.id \\ 2Department of Management, UNIVERSITAS BRAWIJAYA, INDONESIA, E-mail: pusvita.yuana@ub.ac.id \\ ${ }^{3}$ Department of Management, UNIVERSITAS BRAWIJAYA, INDONESIA, E-mail: risca.fa@ub.ac.id \\ ${ }^{4}$ Department of Management, UNIVERSITAS BRAWIJAYA, INDONESIA, E-mail: annisaamirr@gmail.com \\ ${ }^{5}$ Department of Management, UNIVERSITAS BRAWIJAYA, INDONESIA, E-mail: aishakarunia@student.ub.ac.id
}

\begin{abstract}
RESUMEN
El COVID-19 se produjo a principios de 2020 y provocó restricciones sociales, distanciamiento físico e incluso restricciones sociales a gran escala (PSBB) en la ciudad de Malang. Este impacto ha destrozado masivamente las bases sociales y económicas de Indonesia. Esta investigación tiene como objetivo investigar el impacto de la confianza en la vigilancia de la salud, la seguridad percibida y la marca del restaurante, la solidaridad con los servicios de alimentación hacia la intención de volver a visitar, la intención de visitar otros restaurantes, y el boca a boca a través de la satisfacción en los restaurantes de Malang. Doscientos cincuenta encuestados participaron en este estudio. Para lograr el objetivo de este estudio, se utilizó el software SmartPLS3. El método de investigación utilizado es una encuesta mediante la distribución de cuestionarios. Los resultados de la encuesta mediante cuestionarios se introdujeron, tabularon y procesaron para su posterior análisis mediante el software SmartPLS3. Como se predijo, la confianza en la vigilancia de la salud, la seguridad percibida y la marca del restaurante, la solidaridad con los servicios de alimentación tuvieron un efecto significativo en la satisfacción. Además, en este estudio se ha comprobado el efecto de la satisfacción sobre la intención de volver a visitar el restaurante, la intención de visitar otros restaurantes y el boca a boca. Desde un punto de vista práctico, es obvio que para ayudar a los restaurantes a sobrevivir, el gobierno y la comunidad pueden trabajar juntos para crear empatía y solidaridad con los restaurantes, así como cumplir con los protocolos de salud y seguridad.
\end{abstract}

Palabras clave: Confianza en la vigilancia sanitaria; Seguridad percibida y marca de los restaurantes; Solidaridad con los servicios de alimentación; Intención de visita; Boca a boca.

Clasificación JEL: M21, M31, M30

Recibido: 05 de Junio de 2021

Aceptado: 27 de Septiembre de 2021 


\section{Introduction}

In 2020, various countries implemented social distancing, isolation, quarantine, and lockdown policies as a step to reduce the transmission of the coronavirus (Qureshi et al., 2021). Countries' restrictions on human mobilization have had a negative impact on the hotel and restaurant industry (Song et al., 2021). The COVID-19 pandemic has a significant impact on people's lifestyles, both in cities and villages. Even though they are located in different regions, large cities with all their modern facilities and products are still trying to figure out the best way to deal with COVID-19. One of them is to take care of each other and strengthen the awareness to help the residents of the city, especially those who are sick and have lost their jobs. The impact of the coronavirus (COVID-19) is perceived in almost all sectors, including the food and beverage sector such as restaurants. The informal economy was a particularly hard-hit sector during this pandemic. The Central Statistics Agency (BPS) said in February 2019 that the number of persons employed in the informal economy has nearly reached 75 million. In addition, the large-scale social restriction policy in Malang at the beginning of May 2020 caused many residents to lose their jobs due to the loss of many businesses.

The impact of the pandemic on the economy has forced the Indonesian government to provide concessions, including by allowing restaurants to recommence operations by complying with strict health protocols (The Jakarta Post, 2020). The Indonesian Hotel and Restaurant Association (PHRI) reports that 125 to 150 restaurants have closed each month since October 2020, with a total of 1,033 restaurants and hotels permanently closed during the COVID-19 pandemic in Indonesia (Bisnis.com, 2021). Several restaurants experienced losses due to lack of visitors, so they were forced to close their outlets because they were unable to bear even greater losses (Yuniartha, 2020). Burhan (2020) stated that the culinary sector experienced a decrease in daily income reaching $37 \%$. An example of a reputable Restaurant in Indonesia namely Pizza Hut reported on CNBC Indonesia (2020), recorded an $85 \%$ decrease in net income in the first quarter of this year to 6.04 billion rupiah. In fact, in the same period of the previous year, PZZA posted a net profit of 40.17 billion rupiah. Not only in 2020, but also according to the information provided by Secretary-General of the Indonesian Hotel and Restaurant Association (PHRI), Maulana Yusran, the growth of restaurants in 2021 is becoming more and more difficult (Liputan 6, 2021). To prevent the spread of the COVID-19 virus, the government implemented the large-scale social restriction (PSBB) in early May 2020 and the emergency public activity restrictions (PPKM) from June - September 2021 by limiting restaurant hours of operation to only up to 20.00 WIB, food service delivery/takeaway, and applying stricter health protocols (Liputan 6, 2021).

This restriction was welcomed by restaurant entrepreneurs and the public. Although the increase was not very significant, people are back to ordering food either online or visiting restaurants for dinein or takeaway (Lock, 2021). The drive-thru service is also one of the services to meet the needs of today's society (Nair et al., 2021). Various efforts made by the government through the authorities in handling COVID-19 and the commitment of restaurants to comply with health protocols have made some people believe and feel safe to travel to restaurants in the era of the pandemic (Mishra \& Rath, 2020). The success of the restaurant in restoring the trust and sense of security of the community cannot be separated from the restaurant's commitment to creating a safe, healthy, and comfortable situation. Restaurants that already have names tend to have adequate facilities for implementing health protocols (Hakim et al., 2021). Trust that continues that creates a sense of satisfaction and pleasure can also increase revisit intention and the intention to visit other restaurants (Ali et al., 2016). This can also happen in the era of a pandemic.

People are social beings who cannot live alone and depend on others and have a sense of empathy and concern for others (Singer \& Klimecki, 2014). The losses faced by restaurants due to the pandemic resulted in many employees losing their jobs as restaurants continued to experience losses and bankruptcy. The news about this negative impact creates a sense of empathy that leads to solidarity to help people who are impacted by the pandemic (Mishra \& Rath, 2020). This is as stated through the release of the United Nations Development Program (UNDP) that cooperation and solidarity are needed in dealing with the COVID-19 pandemic (Modeer \& Ryott, 2020). If customers or users are 
satisfied, they will generally be loyal and talk about positive things about the product and company to others (Word of Mouth) (Kotler \& Keller, 2016).

In this study, the Health Surveillance Trust; Perceived Safety and Restaurant Brand; Solidarity with The Food Services will be used to analyse its effect on Word of Mouth (WOM), intention to other restaurants and revisit intention mediated by visitor satisfaction to create a comprehensive model of improvement in the restaurant industry in Malang City. In previous studies, satisfaction was only associated with revisit intention as part of loyalty, but in this study in the context of a pandemic satisfaction is not only associated with revisit intention, but also the intention to visit other restaurants. The other restaurant mentioned is however a different restaurant, not related (not from the same owner), so this study will look at the impact of community satisfaction on the Health Surveillance Trust; Perceived Safety and Restaurant Brand; Will Solidarity with The Food Services affect their intention to visit the restaurant they visit and will it increase people's intention to visit other restaurants because they feel that all restaurants will apply the same rules and policies and as a form of solidarity not only in one restaurant but several other restaurants. Through the customer satisfaction obtained, positive information will be conveyed between consumers or through Word of Mouth. Based on a review of the literature on customer satisfaction, this paper details specific areas to provide insights for academics and practitioners to navigate the restaurant industry's service to survive during COVID-19.

\section{Literature Review}

The pandemic that has lasted for 1.5 years since the beginning of 2020 and had a bad influence on various business sectors, one of them is restaurants. Most restaurant sales activities are take-aways or dine-in. However, due to the pandemic, consumers are hesitant to eat at the restaurant and are increasing their concern with the safety and cleanliness of the food served.

In the context of the COVID-19 pandemic, public trust will depend on the performance of the COVID-19 task force. Health surveillance trust is part of the task force in COVID-19 (Modeer \& Ryott, 2020). Trust in health surveillance, which is part of social trust, is defined as a willingness to count on the people in charge of decision-making, such as maintaining technology, the environment, safety, and health. Social trust can reduce the perception of risk and enhance the perception of benefits (Siegrist et al., 2000) that affect a consumer's willingness to purchase a product (Hakim, Zanetta, \& Oliveira, 2021). The government through the COVID-19 task force uses World Health Organization (WHO) standards in dealing with and overcoming the pandemic, including providing a sense of security and avoiding conflict which is the impact of a lack of public trust (Nunkoo \& Ramkissoon, 2012).

In the era of a pandemic, the perception of safety becomes more important to convince consumers that the places they visit are safe and not at risk of spreading the virus. The intention to visit a restaurant can be predicted through the perception of security felt by consumers (Hakim et al., 2021). On the other hand, when the risk faced is perceived as high based on the results of perceived security, there will be rejection and reluctance (Bardon, 2019). In the current context of the COVID-19 crisis, hygiene is a common factor across the various methods offered by different establishments. For this reason, it is highlighted as the primary preventative measure to reduce the risk of COVID-19 spread and support clean and healthy lifestyle behavior (Sifuentes et al., 2014; Vos et al., 2019). Furthermore, Moon et al. (2017) found that among the various variables of the physical environment, cleanliness had a positive impact on customer satisfaction; Barber et al. (2011) found that consumer satisfaction and loyalty intentions were influenced by hygiene. Not only during the pandemic, but restaurant cleanliness is also a concern for restaurants because these services attract consumers to buy their products (Pathmanathan et al., 2019). In addition, consumers feel satisfied when service quality is prioritized (Ardani et al., 2019).

The impact of the pandemic has caused many businesses to collapse. This phenomenon encourages mutual help and dependence between each other to survive during this pandemic. Several regulations that must be obeyed by businesses owners, workers, and visitors or consumers are stated in the decision of the Minister of Health of the Republic of Indonesia, including always using masks, 
maintaining distance, online ordering services or delivery services, or drive-thrus (Kemenkes, 2020). This creates new habits and is expected to create a sense of solidarity in the food services. Solidarity among the restaurants has a significant effect on intentions to visit restaurants during the pandemic in Brazil (Hakim et al., 2021).
H1 Health Surveillance Trust affects satisfaction.
H2 Perceived Safety affects satisfaction.
H3 Solidarity with The Food Services affects satisfaction.

Consumers who have fulfilled their desires from the restaurant will feel satisfied. The results of Han and Hyun (2017) show that the satisfaction that has been obtained by consumers will increase the consumer's desire to repurchase food from the restaurant. Previous research found that the high quality of staff and food service plays an important role in increasing customer satisfaction in a luxury hotel restaurant, which ultimately increases the intention to repurchase restaurant products and purchase other restaurant products within the same hotel property (Han \& Hyun, 2017). In this case, with customer satisfaction customers will not only visit the same restaurant, but also consumers want to make purchases at other restaurants that also provide the same service. Consumers who are satisfied with the services provided by the restaurant will increase the desire to revisit the restaurant (Anggraeni et al., 2020; Ardani et al., 2019).

The consumer's intention to repurchase and the consumer's desire to recommend the food to others is also a general measurement of consumer behaviour (Chen \& Tsai, 2007). The consumer who is satisfied with the food served will affect consumer promotion through word of mouth (WOM) (Lai, 2020). WOM itself is a marketing communication activity through promotions carried out by customers to other customers, either verbally, in writing or electronically that is used by the public to exchange ideas about their experiences and knowledge of a company, product, or service (Latief, 2018). The benefits of WOM are that it can convince other customers and can be an effective marketing method because it comes from consumers to consumers and for consumers, even consumers can act as cheap supervisors (Kotler \& Keller, 2016). In addition, WOM can influence several factors such as consumer choice, service switching, purchasing decisions, perceptions of products/services (Kundu \& Sundara Rajan, 2017).

$$
\begin{aligned}
& \text { H4 Satisfaction affects Revisit Intention. } \\
& \text { H5 Satisfaction affects the Intention to visit other restaurants. } \\
& \text { H6 Satisfaction affects Word of Mouth (WOM). }
\end{aligned}
$$

H7 Satisfaction acts as a mediator between Health Surveillance Trust, Perceived Safety, Solidarity with The Food Services, Revisit Intention, Intention to visit other restaurants, Word of Mouth (WOM).

\section{Methodology}

The type of research conducted is explanatory which aims to test theories or hypotheses to see a causal relationship between the variables studied, namely health surveillance trust, perceived safety and restaurant brand, solidarity with the food services, satisfaction, revisit intention, intention to visit other restaurants, word of mouth. The resulting conceptual model becomes a reference for developing an applicable model to increase Revisit Intention, Intention to Visit Other Restaurants, Word of Mouth of restaurant visitors.

This research data has been distributed to a sample of restaurant visitors in Malang which has been determined by purposive sampling. Population in this research are restaurant diners in Malang. Sampling technique is conducted by using non-probability through the purposive sampling technique with the sample of 250 respondents to test the research conceptual model, the results of the survey results through questionnaires were inputted, tabulated, and processed were then analysed using the modelling of partial least squares structural equations (PLS-SEM) through SmartPLS3 software. 


\section{Results and Discussion}

The results of the outer model test on convergent validity in Table 1 show that the loading factor value of each indicator in the variable is $>0.7$ and the AVE or Average Variance Inflation Factor value in all variables is $>0.5$. this shows that the seven variables and indicators that make up the variables are categorized as valid and indicate that there is a high correlation between indicators and variables.

Table 1 Convergent and Reliability

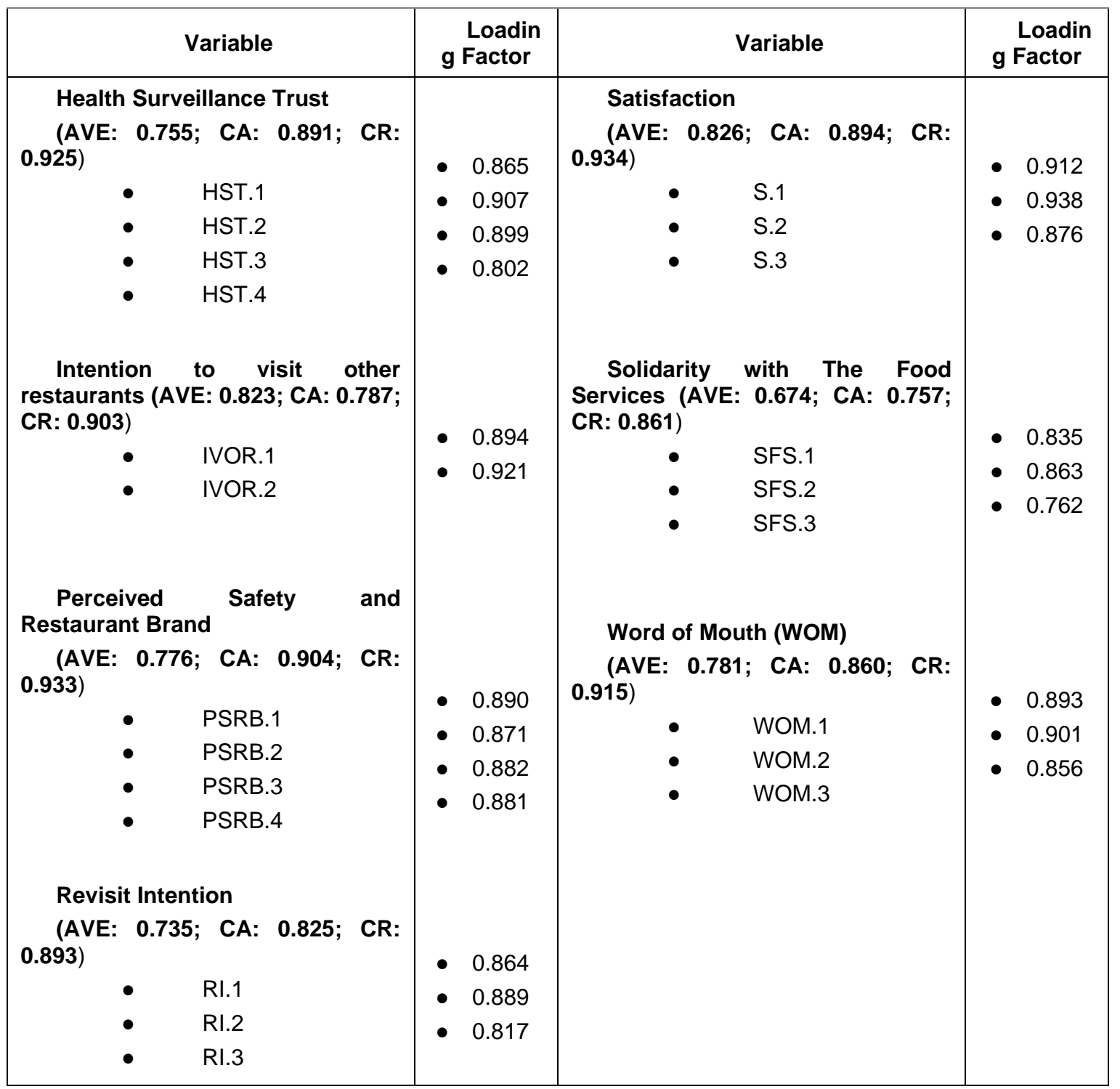

Abbreviation: AVE (Average Variance Extracted); CA (Cronbach Alpha); CR (Composite Reliability) Source: Data Analysis using SmartPLS, 2021

In discriminant validity, Table 2 shows that the cross-loading value of the indicators forming the variables is $>0.7$ and the cross-loading value of the variable indicators is greater than the cross-loading value of other variable indicators. This shows that all the forming indicators of the seven variables are categorized as valid. Finally, the reliability test in Table 1 shows the value of Cronbach's alpha $>0.7$ and the value of composite reliability $>0.6$ this shows that all variables are reliable. 
Table 2 Discriminant Validity

\begin{tabular}{|l|l|l|l|l|l|l|l|}
\hline & HST & IVOR & PSRB & RI & S & SFS & WOM \\
\hline HST.1 & 0.865 & 0.481 & 0.577 & 0.483 & 0.635 & 0.537 & 0.636 \\
HST.2 & 0.907 & 0.476 & 0.599 & 0.498 & 0.663 & 0.534 & 0.668 \\
HST.3 & 0.899 & 0.488 & 0.613 & 0.600 & 0.637 & 0.561 & 0.618 \\
HST.4 & 0.802 & 0.368 & 0.444 & 0.555 & 0.522 & 0.456 & 0.514 \\
IVOR.1 & 0.472 & 0.894 & 0.492 & 0.500 & 0.513 & 0.835 & 0.501 \\
IVOR.2 & 0.481 & 0.921 & 0.559 & 0.418 & 0.590 & 0.863 & 0.565 \\
PSRB. & 0.578 & 0.519 & 0.890 & 0.414 & 0.712 & 0.551 & 0.609 \\
1 & & & & & & & \\
PSRB. & 0.527 & 0.438 & 0.871 & 0.400 & 0.636 & 0.478 & 0.577 \\
3 PSRB. & 0.593 & 0.485 & 0.882 & 0.382 & 0.642 & 0.528 & 0.611 \\
PSRB. & 0.581 & 0.593 & 0.881 & 0.451 & 0.732 & 0.610 & 0.656 \\
4 & & & & & & & \\
RI.1 & 0.526 & 0.428 & 0.405 & 0.864 & 0.478 & 0.553 & 0.436 \\
RI.2 & 0.580 & 0.501 & 0.467 & 0.889 & 0.623 & 0.568 & 0.642 \\
RI.3 & 0.442 & 0.327 & 0.300 & 0.817 & 0.369 & 0.441 & 0.356 \\
S.1 & 0.618 & 0.593 & 0.731 & 0.506 & 0.912 & 0.615 & 0.770 \\
S.2 & 0.652 & 0.566 & 0.693 & 0.594 & 0.938 & 0.627 & 0.779 \\
S.3 & 0.669 & 0.503 & 0.690 & 0.515 & 0.876 & 0.592 & 0.695 \\
SFS.1 & 0.472 & 0.894 & 0.492 & 0.500 & 0.513 & 0.835 & 0.501 \\
SFS.2 & 0.481 & 0.921 & 0.559 & 0.418 & 0.590 & 0.863 & 0.565 \\
SFS.3 & 0.531 & 0.485 & 0.465 & 0.604 & 0.548 & 0.762 & 0.465 \\
WOM.1 & 0.620 & 0.561 & 0.616 & 0.566 & 0.764 & 0.588 & 0.893 \\
WOM.2 & 0.616 & 0.497 & 0.617 & 0.528 & 0.720 & 0.545 & 0.901 \\
WOM.3 & 0.633 & 0.501 & 0.616 & 0.447 & 0.699 & 0.519 & 0.856 \\
\hline
\end{tabular}

Abbreviation: HST (Health Surveillance Trust), IVOR (Intention to visit other restaurant), PSRB (Perceived Safety and Restaurant Brand), RI (Revisit Intention), S (Satisfaction), SFS (Solidarity with The Food Services), WOM (Word Of Mouth) Source: Data Analysis using SmartPLS, 2021

\subsection{Inner Model Test}

The results of the inner model on the R-square in Table 3 show the results for the variable intention to visit other restaurants is 0.373 , Revisit Intention 0.352 , Satisfaction 0.703 , and Word of Mouth 0.679. This means that the variables Intention to Visit Other Restaurant and revisit intention can be explained by the mediating variable satisfaction and independent variables health surveillance trust, perceived safety and restaurant brand, solidarity with the food services by $37.3 \%$ and $35.2 \%$ which are included in the weak category. Meanwhile, Word of Mouth is included in the moderate category, which is $70.3 \%$. Furthermore, the satisfaction variable can be explained by the variable of intention to visit other restaurants of $67.9 \%$ which is included in the moderate category.

The results of the summary direct effect hypothesis test can be seen in Table 4: health surveillance trust, perceived safety and restaurant brand, solidarity with the food services, showed a significant ( $p$ $<0.05$ and T-Statistic $>1.96$ ) affecting satisfaction with this $\mathrm{H} 1, \mathrm{H} 2$, and $\mathrm{H} 3$ were accepted. Satisfaction showed a significant influence $(p<0.05$ and T-Statistic $>1.96)$ on the intention to visit other restaurants and Word of Mouth (WOM) with this $\mathrm{H} 4, \mathrm{H} 5$, and $\mathrm{H} 6$ were accepted. Furthermore, the indirect effect seen in Table 5 shows that the mediating variable satisfaction significantly mediates Word of Mouth 
(WOM) to the intention to visit other restaurants and revisit intention can be explained by the mediating variable satisfaction and independent variables health surveillance trust, perceived safety and restaurant brand, solidarity with the food services.

Figure 1 Inner Model Test

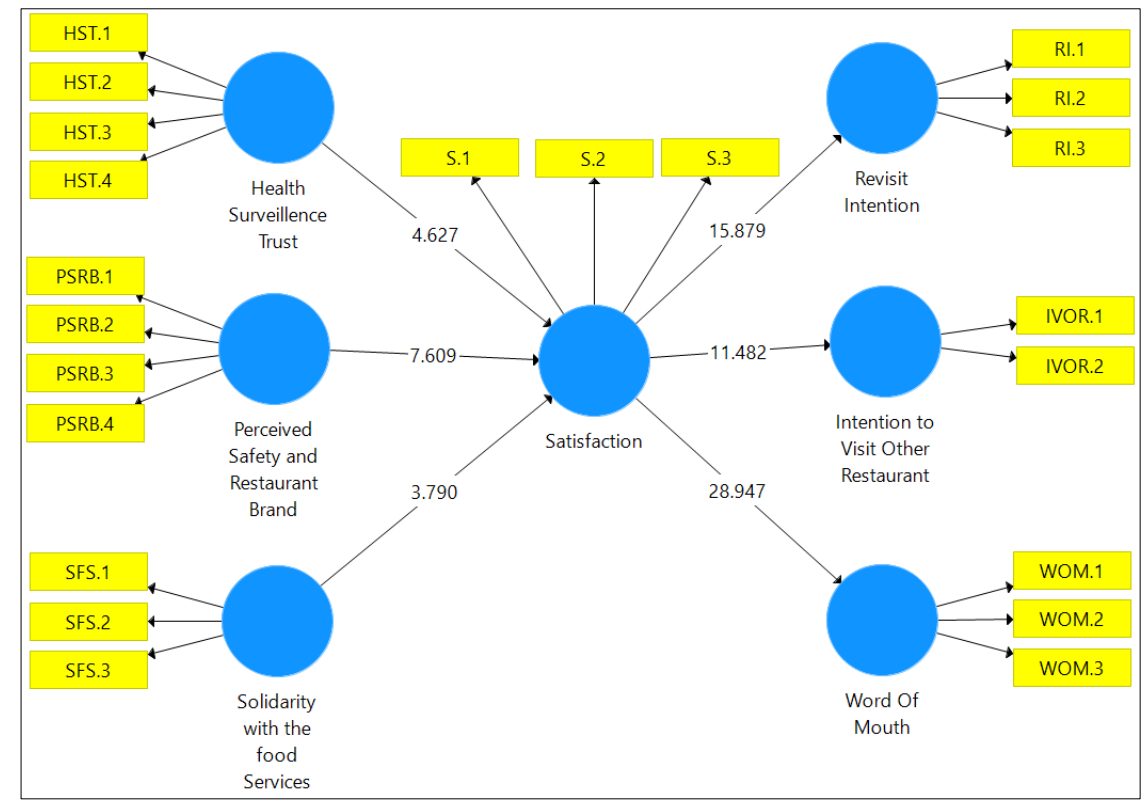

Source: Data Analysis using SmartPLS, 2021

Table 3 R-Square Value

\begin{tabular}{|lc|}
\hline & $\begin{array}{c}\text { R } \\
\text { Square }\end{array}$ \\
\hline Intention to Visit Other Restaurant & 0.373 \\
Revisit Intention & 0.352 \\
Satisfaction & 0.703 \\
Word Of Mouth & 0.679 \\
\hline
\end{tabular}

Source: Data Analysis using SmartPLS, 2021

Table 4 Path Coefficient

\begin{tabular}{|c|c|c|c|c|c|c|c|}
\hline & & $\begin{array}{l}\text { Origina } \\
\text { I Sample } \\
\text { (0) }\end{array}$ & $\begin{array}{c}\text { Sample } \\
\text { Mean (M) }\end{array}$ & $\begin{array}{l}\text { Standa } \\
\text { rd } \\
\text { Deviation } \\
\text { (STDEV) }\end{array}$ & $\begin{array}{l}\text { T Statistics } \\
\text { (|O/STDEV|) }\end{array}$ & $\begin{array}{c}\mathbf{P} \\
\text { Values }\end{array}$ & $\begin{array}{l}\text { Informatio } \\
\mathbf{n}\end{array}$ \\
\hline \multicolumn{2}{|c|}{ HST $->\mathrm{S}$} & 0.281 & 0.281 & 0.062 & 4.507 & 0.000 & Supported \\
\hline \multicolumn{2}{|c|}{$\mathrm{S}^{\text {PSRB -> }}$} & 0.457 & 0.455 & 0.060 & 7.662 & 0.000 & Supported \\
\hline \multicolumn{2}{|c|}{ SFS-> S } & 0.222 & 0.224 & 0.061 & 3.643 & 0.000 & Supported \\
\hline \multicolumn{2}{|c|}{$\mathbf{S}->\mathbf{R I}$} & 0.593 & 0.593 & 0.036 & 16.366 & 0.000 & Supported \\
\hline $\begin{array}{r}\text { S } \\
\text { IVOR }\end{array}$ & $->$ & 0.611 & 0.613 & 0.050 & 12.310 & 0.000 & Supported \\
\hline $\begin{array}{r}\mathrm{s} \\
\text { WOM }\end{array}$ & $->$ & 0.824 & 0.824 & 0.028 & 29.476 & 0.000 & Supported \\
\hline
\end{tabular}

Abbreviation: HST (Health Surveillance Trust), IVOR (Intention to visit other restaurant), PSRB (Perceived Safety and Restaurant Brand), RI (Revisit Intention), S (Satisfaction), SFS (Solidarity with The Food Services), WOM (Word of Mouth) Source: Data Analysis using SmartPLS, 2021 
Table 5 Specific Indirect Effect

\begin{tabular}{|c|c|c|c|c|c|c|}
\hline & $\begin{array}{l}\text { Origin } \\
\text { al Sample } \\
\text { (0) }\end{array}$ & $\begin{array}{c}\text { Sam } \\
\text { ple } \\
\text { Mean } \\
\text { (M) }\end{array}$ & $\begin{array}{l}\text { Stand } \\
\text { ard } \\
\text { Deviation } \\
\text { (STDEV) }\end{array}$ & $\begin{array}{l}\text { T Statistics } \\
(\mid \text { O/STDEV } \mid)\end{array}$ & P Values & Information \\
\hline HST $->$ S $->$ RI & 0.167 & 0.167 & 0.040 & 4.198 & 0.000 & Supported \\
\hline $\begin{array}{l}\text { HST } \\
\text { IVOR }\end{array}$ & 0.171 & 0.172 & 0.039 & 4.399 & 0.000 & Supported \\
\hline $\begin{array}{llll}\text { HST } & \rightarrow & \mathbf{S} & \rightarrow \\
\text { WOM } & & & \end{array}$ & 0.231 & 0.232 & 0.053 & 4.340 & 0.000 & Supported \\
\hline PSRB $->S$-> RI & 0.271 & 0.269 & 0.036 & 7.502 & 0.000 & Supported \\
\hline $\begin{array}{l}\text { PSRB } \rightarrow \text { S } \rightarrow \\
\text { IVOR }\end{array}$ & 0.279 & 0.278 & 0.039 & 7.084 & 0.000 & Supported \\
\hline $\begin{array}{l}\text { PSRB } \rightarrow \text { S } \rightarrow \\
\text { WOM }\end{array}$ & 0.376 & 0.374 & 0.050 & 7.552 & 0.000 & Supported \\
\hline SFS $->$ S $->$ RI & 0.131 & 0.133 & 0.038 & 3.450 & 0.001 & Supported \\
\hline $\begin{array}{llll}\text { SFS } & -> & S & -> \\
\text { IVOR }\end{array}$ & 0.135 & 0.139 & 0.044 & 3.100 & 0.002 & Supported \\
\hline $\begin{array}{l}\text { SFS } \\
\text { WOM }\end{array}$ & 0.183 & 0.185 & 0.051 & 3.608 & 0.000 & Supported \\
\hline
\end{tabular}

Abbreviation: HST (Health Surveillance Trust), IVOR (Intention to visit other restaurant), PSRB (Perceived Safety and Restaurant Brand), RI (Revisit Intention), S (Satisfaction), SFS (Solidarity with The Food Services), WOM (Word of Mouth)

Source: Data Analysis using SmartPLS, 2021

\subsection{Discussion}

All hypotheses in this study were accepted based on the analysis using smartPLS seen in Table 4 and Table 5. The results showed that health surveillance trust, perceived safety and restaurant brand, and solidarity with the food services had a positive and significant effect on satisfaction. This shows that the Health Surveillance Trust or public trust in the COVID-19 task force in regulating health safety during the current pandemic, one of which is the policy issued for restaurants or restaurants after reopening. The government and the COVID-19 task force have made several policies by implementing several health protocols that make people in Malang City feel secure related to health in restaurants and feel satisfied when visiting them. In previous studies, Brazil has also proven that the social trust factor affects the decision to visit a restaurant, trust in the government positively affects disease denial and moderate's intention to visit restaurants (Hakim et al., 2021). With the restaurant providing the health protocols, they have created a good reputation for their brand or restaurant which in turn correlates with customers' trust and satisfaction. Moreover, Widjaja et al., (2020) announce that the increasing revisit intention is built by the reputation of the destination also in terms of products and services. The development reputation itself is done by encouraging responsibility among visitors and restaurant's management.

During the current pandemic, the feeling of safety provided by restaurants with brands that are well known in Malang and those that were known before the pandemic makes consumers feel satisfied when visiting. This is supported by the time of distributing the questionnaire, the statement that consumers always choose to go to a restaurant that is known or frequently visited gets the highest score. The feeling of safety obtained by consumers shows the quality of the restaurant where according to Ryu and Han (2010) the overall quality of a restaurant product includes tangible and intangible.

The social solidarity of the poor city community for food service businesses such as restaurants influences customer satisfaction when visiting. This satisfaction is possible because of the community's empathy for not closing during a pandemic by visiting and/or going to restaurants or restaurants with 
these decisions making consumers happy and satisfied. This action has given the sense of being supportive and sense of togetherness during the pandemic.

The results also show that satisfaction has a direct effect on revisit intention, intention to visit other restaurants, and Word of Mouth (WOM). When consumers are satisfied to visit restaurants, both dinein and take away during the current pandemic, it can influence them to revisit the restaurant and other restaurants in the vicinity and encourage consumers to do Word of Mouth (WOM). The availability of health protocols, provides satisfaction with a sense of security, and trust in the quality and service of restaurants, where when customers are satisfied with their experience, they are more likely to show the positive intentions towards the product or service provided by the restaurant including customers will confidently to do word of mouth (WOM). This happens because when consumers are satisfied, it is very possible for consumers to revisit intentions, and spread good things by word of mouth (WOM) (Kotler \& Keller, 2016). Previous research also at Luxury Hotel Restaurants in Korea showed that satisfaction had a significant effect on the intention to revisit hotel restaurants (Han \& Hyun, 2017).

In the indirect effect test in Table 5, it was found that the mediating variable satisfaction was accepted and played a significant role in mediating between health surveillance trust, perceived safety and restaurant brand, solidarity with the food services on revisit intention, intention to visit other restaurants, and Word of Mouth (WOM). This shows that the confidence of the people of Malang City in the COVID-19 task force in regulating health safety, especially policies for restaurants or restaurants after reopening during this pandemic, makes people feel guaranteed regarding health safety in restaurants that make consumers satisfied when visiting and can make consumers to revisit intention, intention to visit other restaurants and encourage Word of Mouth (WOM). The regulation given by the government has created a standard for restaurants to apply their health protocols. In addition, those who do not obey the regulation will possibly be banned or closed by the institution. Thus, the regulation or standard applied by the restaurants will support the safety of the people who intend to buy food and beverages from the restaurant. The feeling of security given by restaurants with wellknown brands in Malang and those they knew before the pandemic also made people feel satisfied when visiting and were able to create and encourage consumers to revisit intentions, visit other restaurants and encourage Word of Mouth (WOM).

During the COVID-19 pandemic, almost all areas are impacted by the pandemic. Therefore, the government and civil society have taken a number of measures to prevent COVID-19. One of the government's efforts is to implement the PSBB policy, which will significantly impact tourism, including the restaurant industry. The other impacts are trauma, the loss of someone they love, and the uncertainty that leads to fear and panic. With the numerous losses suffered by the community, the social solidarity which exists in the community will increase. In addition, this solidarity is closely bound up with the character of society.

People begin to remind each other to follow the health protocols, to stay healthy and many donations were held for those who need it. The social solidarity built by the people of the poor city towards food service businesses such as going to restaurants to prevent closures and preventing unemployed employees during this pandemic through their visits creates satisfaction and can encourage consumers to revisit intention, intention to visit other restaurants and encourage Word of Mouth (WOM).

The implication of this research is that in the restaurant industry, restaurants can not only see for visitors who visit one restaurant, but also must see how visits to other restaurants are, and what people say about the restaurant that they are satisfied with their visit. When these three components are good, it shows that the restaurant can survive during the pandemic. These three components can be achieved if the visitors are satisfied. Visitors will be satisfied if they believe in the supervision provided by the government and trust in the brand. The interesting thing here is how visitors have empathy as a form of solidarity so that restaurants can survive during the pandemic. 


\section{Conclusion}

Based on the results of this study, it certainly has a good and positive impact on the sustainability of the restaurant industry in Malang City during the current pandemic. It is known from the results of this study that health surveillance trust, perceived safety and restaurant brand, and solidarity with the food services have an influence on the satisfaction variable. This is because the people of Malang City have trusted the COVID-19 task force related to health in restaurants to the people in Malang City so that they feel guaranteed safety and are satisfied when visiting them. The feeling of security provided by restaurants with brands that are well known in Malang and those they had known before the pandemic also made people feel satisfied when visiting. Through the social solidarity of the people in Malang City, such as visiting restaurants during the current pandemic, provide its own satisfaction for consumers when visiting. If satisfied, consumers can revisit the restaurant and other restaurants around it and be encouraged to do Word of Mouth (WOM). From the results of this study, it is recommended that restaurants in Malang can improve health protocol programs at their locations such as requiring visitors to use masks, maintain social distance and apply health protocols to employees such as using face shields, masks, and gloves. Paying more attention to the quality of their food and beverages is also necessary to avoid any complaints. By carrying out the health protocols that have been determined by the government, it is hoped that visitors can have a sense of security and trust when buying products at the restaurant that leads to satisfaction. This study predicts how restaurants can survive during the pandemic season, not testing to see the world more realistically. Thus, further research needs to pay more attention to statistical techniques that are more rigid so that they can get a real picture. Moreover, upcoming research should add other factors that can boost satisfaction such as the use of digital technology, considering technology has become more dominant during COVID-19 and will continuously thrive in 2025 (Anderson, Rainie \& Vogels, 2021). Therefore, it is worth studying how technology-based approaches should be introduced in restaurants to improve customer satisfaction.

\section{References}

1. Ali, F., Ryu, K., \& Hussain, K. (2016). Influence of Experiences on Memories, Satisfaction and Behavioral Intentions: A Study of Creative Tourism. Journal of Travel and Tourism Marketing, 33(1), 85 - 100. https://doi.org/10.1080/1054840 8.2015.1038418

2. Anderson, J., Rainie, L., \& Vogels, E. A. (2021, April 5). Experts say the 'new normal' in 2025 will be far more tech-driven, presenting more big challenges. Pew Research Center: Internet, Science \& tech. https://www.pewresearch.org/internet/2021/02/18/experts-say-the-new-normal-in2025-will-be-far-more-tech-driven-presenting-more-big-challenges/.

3. Anggraeni, A., Sulistyo, L. I. H., \& Affandy, N. (2020). The antecedents of satisfaction and revisit intention for full-service restaurants: An empirical study of the food and beverage industry in Jakarta. International Journal of Asian Business and Information Management, 11(3), 101-118. https://doi.org/10.4018/IJABIM.2020070107

4. Ardani, W., Rahyuda, K., Giantari, I. G., \& Sukaatmadja, I. P. (2019). Customer Satisfaction and Behavioral Intentions in Tourism: A Literature Review. International Journal of Applied Business and International Management, 4(3), 84-93. https://doi.org/10.32535/ijabim.v4i3.686

5. Barber, N., Goodman, R.J., Goh, B.K. (2011). Restaurant consumers repeat patronage: A service quality concern. International Journal of Hospitality Management, 30 (2), 329-336.

6. Bardon, A. (2019). The Truth About Denial: Bias and Self-Deception in Science, Politics, and ... Adrian Bardon - Google Books. Oxford University Press.

https://books.google.co.id/books?hl=en\&lr=\&id=VParDwAAQBAJ\&oi=fnd\&pg=PP1\&ots=A6ywp afFo_\&sig=4_XA9h7AYlynqGKEd5Wi5bkCn-4\&redir_esc=y\#v=onepage\&q\&f=f alse

7. Burhan, Fahmi Ahmad. 2020. Bisnis Anjlok akibat Pandemi Corona, UMKM Bisa Ubah Strategi Usaha. https://katadata.co.id/berita/2020/04/15/bisnis-anjlok-akibat-pandemi-corona-umkmbisa-ubah-strategi-usaha). 
8. Bisnis.com. (2021). Thousands of Hotels and Restaurants Permanently Closed Due to the Covid19 Pandemic. https://ekonomi.bisnis.com/read/20210205/12/1352941/ribuan-hotel-danrestoran-tutup-permanen-akibat-pandemi-covid-19.

9. Chen, C. F., \& Tsai, D. (2007). How destination image and evaluative factors affect behavioral intentions? Tourism management, 28(4), 1115-1122.

10.CNBC Indonesia. Dampak PSBB, Laba Pizza Hut Indonesia Anjlok 85\% di Q1. https://www.cnbcindonesia.com/market/20200702112828-17-169647/dampak-psbb-labapizza-hut-indonesia-anjlok-85-di-q1

11. Hakim, M. P., Zanetta, L. D. A., \& da Cunha, D. T. (2021). Should I stay, or should I go? Consumers' perceived risk and intention to visit restaurants during the COVID-19 pandemic in Brazil. Food Research International, 141(January), 110152. https://doi.org/10.1016/j.foodres.2021.110152

12. Hakim, M. P., Zanetta, L. D., Oliveira, J. M. d. (2021). The mandatory labeling of genetically modified foods in Brazil: Consumer's knowledge, trust, and risk perception. Food Research International 132 (2020) 109053. https://doi.org/10.1016/j.foodres.2020.109053

13.Han, H. \& Hyun, S. S. (2017). Impact of hotel-restaurant image and quality of physicalenvironment, service, and food on satisfaction and intention. International Journal of Hospitality Management 63 (2017) 82-92.

14. Kemenkes. (2020). Health Protocols for the Community in Public Places and Facilities in the Context of Prevention and Control of Corona Virus Disease 2019 (COVID-19). Retrivied February 23 from

http://hukor.kemkes.go.id/uploads/produk_hukum/KMK_No_HK_01_07-MENKES-382-

2020_ttg_Protokol_Kesehatan_Bagi_Masyarakat_di_Tempat_dan_Fasilitas_Umum_Dalam_Ran gka_Pencegahan_COVID-19.pdf

15.Kotler, P. \& Keller, K. L. (2016). Marketing Management $15^{\text {th }}$ edition. Person Education Limited. England

16.Kundu, S., \& Sundara Rajan, R. (2017). Word of Mouth: A Literature Review. International Journal of Economics \& Management Sciences, 06(06). https://doi.org/10.4172/2162-6359.1000467

17.Lai, I. K. W. (2020). An examination of satisfaction on word of mouth regarding Portuguese foods in Macau: Applying the concept of integrated satisfaction. Journal of Hospitality and Tourism Management, 43, 100-110. https://doi.org/10.1016/j.jhtm.2020.02.011

18.Latief, R. (2018). Word of Mouth Communication Sales Product. Media Sahabat Cendikia, Surabaya

19.Liputan 6. (2021). Crazy Covid-19 Cases, PHRI: 2021 is getting tougher. https://www.liputan6.com/bisnis/read/4589277/kasus-covid-19-menggila-phri-tahun-2021semakin-berat

20.Lock, S. (2021). COVID-19: daily year-on-year global restaurant dining decline 2021 / Statista. https://www.statista.com/statistics/1103928/coronavirus-restaurant-visitation- impact/

21.Mishra, C., \& Rath, N. (2020). Social solidarity during a pandemic: Through and beyond Durkheimian Lens. Social Sciences \& Humanities Open, 2(1), 100079.

https://doi.org/10.1016/j.ssaho.2020.100079

22.Modeer, U., \& Ryott, A. (2020). COVID-19: A reminder of the power of hope and solidarity / UNDP. https://www.undp.org/content/undp/en/home/blog/2020/COVID-19-- a-reminder-of-thepower-of-hope-and-solidarity.html

23.Moon, H., Yoon, H., Han, H. (2017). The effect of airport atmospherics on satisfaction and behavioral intentions: testing the moderating role of perceived safety. Journal of Travel and Tourism Marketing, 34 (6), 749-763.

24.Nair, R. K., Sinha, R., Crasto, S. G., Kian, K. W., Kee, D. M., Binti Abdullah, S. A., Ninti Zaidi, S. N., En, T. S., Jain, A. K., Valecha, P. M., \& Ganatra, V. (2021). The effect of Starbucks Marketing Campaigns on Consumer Buying Behaviour. Asia Pacific Journal of Management and Education, 4(1), 72-81. https://doi.org/10.32535/apjme.v4i1.1052

25.Nunkoo, R., \& Ramkissoon, H. (2012). Power, trust, social exchange, and community support. Annals of Tourism Research, 39(2), 997-1023. https://doi.org/10.1016/j.annals.2011.11.017 
26.Pathmanathan, K. A. P., Kee, D. M., Pandiyan, S. A. L., Yuganathan, J. A. L., Sivakumaran, P. N., \& Alrashed, Y. T. (2019). Health Threats by McDonald's. Journal of The Community Development in Asia, 2(3), 45-51. https://doi.org/10.32535/jcda.v2i3.580

27.Qureshi, A. I., Suri, M. F. K., Chu, H., Suri, H. K., \& Suri, A. K. (2021). Early mandated social distancing is a strong predictor of reduction in peak daily new COVID-19 cases. Public Health, 190, 160-167. https://doi.org/https://doi.org/10.1016/j.puhe.2020.10.015

28.Ryu, K., \& Han, H. (2010). Influence of the quality of food, service, and physical environment on customer satisfaction and behavioral intention in quick-casual restaurants: Moderating role of perceived price. Journal of Hospitality \& Tourism Research, 34(3), 310-329. https://doi.org/10.1177/1096348009350624.

29.Siegrist, M., Cvetkovich, G., \& Roth, C. (2000). Salient value similarity, social trust, and risk/benefit perception. Risk Analysis, 20(3), 353-362.

https://doi.org/10.1111/0272-4332.203034

30.Sifuentes, L.Y., Berba, C.P., Koenig, D.W., Phillips, R.L., Reynolds, K.A. (2014). Use of hygiene protocols to control the spread of viruses in a hotel. Food and Environmental Virology, 6 (3), 175181.

31.Singer, T., \& Klimecki, O. M. (2014). Empathy and compassion. Current Biology, 24(18), R875R878. https://doi.org/10.1016/j.cub.2014.06.054

32.Song, H. J., Yeon, J., \& Lee, S. (2021). Impact of the COVID-19 pandemic: Evidence from the U.S. restaurant industry. International Journal of Hospitality Management, 92(September 2020), 102702. https://doi.org/10.1016/j.ijhm.2020.102702

33. The Jakarta Post. (2020). Govt plans to reopen economy by Q3 as experts caution against COVID19 "second wave" - Business - The Jakarta Post.

https://www.thejakartapost.com/news/2020/05/12/govt-plans-to-reopen-economy-by-q3-asexperts-caution-against-covid-19-second-wave.html

34.Vos, M.C., Galetzka, M., Mobach, M.P., van Hagen, M., Pruyn, A.T.H. (2019). Measuring perceived cleanliness in service environments: Scale development and validation. International Journal of Hospitality Management, 83, 11-18.

35.Widjaja, Y. I., Khalifa, G. S., \& Abuelhassan, A. E. (2020). The Effect of Islamic Attributes and Destination Affective Image on the Reputation of the Halal Tourism Destination of Jakarta. Journal of Environmental Management and Tourism, 11(104), 1. doi:10.14505// jemt. V11.2(42).08

36.Yuniartha, L. (2020, July 14). Hotel, Restaurant Industry in Indonesia Loses \$4.8b Due to COVID19 Pandemic. https://go.kompas.com/read/2020/07/14/235516474/ hotel-restaurant-industryin-indonesia-loses-48b-due-to-COVID-19-pandemic 